\title{
Pertahanan Pangan Di Era Pandemi Covid 19
}

\author{
${ }^{1 *}$ Muhammad Saddam, ${ }^{2}$ Jamaluddin Ali, ${ }^{3}$ Najibullah, ${ }^{4}$ Parmuji, ${ }^{5}$ Agus Suprayogi \\ STIE Hidayatullah Depok, Depok, Jawa Barat, Indonesia \\ *muhammad.sadam@stiehidayatullah.ac.id
}

\begin{abstract}
Abstrak
Pengabdian Kepada Masyarakat (PKM) adalah suatu kegiatan intrakurikuler yang memadukan pelaksanaan tri darma perguruan tinggi (Pendidikan, penelitian, dan pengabdian kepada masyarakat), salah satu kegiatan konkritnya adalah Kuliah Kerja Nyata yang dilaksanakan oleh mahasiswa dibawah pengawasan dosen pembimbing. Tujuan utama dalam kegiatan ini sebagai pemenuhan dan pelaksanaan tri dharma perguruan tinggi yang harus dijalankan oleh setiap civitas academik perguruan tinggi. PKM yang beretempat di Marhamah Foundation (Kota Depok) ini untuk membantu suksesnya kegiatan pengumpulan dan penyaluran Sembilan Bahan Pokok (Sembako) kepada masyarakat sekitar yang terdampak pandemic covid 19. Adpun tema yang diangkat adalah Pertahanan Pangan di Era Pandemi Covid 19. Perencanan program ini akan berkerjasama dengan marhamah foundation dengan harapan kegiatan ini bisa berjalan dengan baik sesuai dengan apa yang diharapkan. Mengingat bahwa marhamah foundation adalah Yayasan charity non provit maka kegiatan yang akan dikerjasamakan adalah membangun fanspage social media, membuat konten, menawarkan program kepada para donator, dan penyaluran bantuan kepada masyarakat terdampak pandemi.
\end{abstract}

Kata Kunci: KKN, Marhamah Foundation, Charity.

\begin{abstract}
Devotion to social community (PKM) is an extracurricular activity that combines the implementation of Tridharma of higher education (education, research, and community service). One of its concurrent activities is a real-life work course carried out by college teachers. The main objective in this activity is the realization and execution of a Tridharma of higher education that should be run by any civitas academically. The PKM that replaces at the Marhamah Foundation (Depok City) to the general population affected by Covid-19. The topic raised is the food defends of the pandemic. The design of the program will work with the Marhamah Foundation, in the hope that it will work out properly. Given that the Marhamah Foundation is the charity non-profit foundation, the activities to be collaborated are constructing social media, fans page, creating content, offering programs to the donors, and delivering aid to communities affected by the pandemic.
\end{abstract}

Kata Kunci: KKN, Marhamah Foundation, Charity.

\section{PENDAHULUAN}

Menurut UU No. 20 Tahun 2003 pasal 3 Tentang Sistem Pendidikan Nasional, tujuan pendidikan nasional adalah untuk mengembangkan potensi peserta didik agar menjadi manusia yang beriman dan bertakwa kepada Tuhan Yang Maha Esa, berakhlak mulia, sehat, berilmu, cakap, kreatif, mandiri, dan menjadi warga negara yang demokratis serta bertanggung jawab.

PKM yang diaplikasikan dalam bentuk Kuliah Kerja Nyata (KKN) adalah kegiatan yang memiliki hubungan dengan berbagai disiplin ilmu. Pendekatan yang digunakan adalah pendekatan interdisipliner dan lintas sectoral. Kegiatan dan pengelolaan PKM ini dapat menjamin diperolehnya pengalaman belajar, melakukan kegiatan pembangunan masyarakat secara kongkrit yang bermanfaat bagi civitas akademik dan masyarkat dimana kegiatan ini dilaksanakan. Selain itu, kegiatan dan pengelolaan PKM diarahkan untuk menjamin keterkaitan antara dunia akademik teoritik dan dunia empirik. 


\section{METODE}

Metode pelaksanaan pengabdian kepada masyarakat ini diawali dengan melakukan observasi lapangan dan koordinasi dengan mitra. Metode kegiatan ini adalah adalah membangun fanspage social media, membuat konten, menawarkan program kepada para donator, dan penyaluran bantuan kepada masyarakat sekitar yang terdampak pandemi. Covid 19.

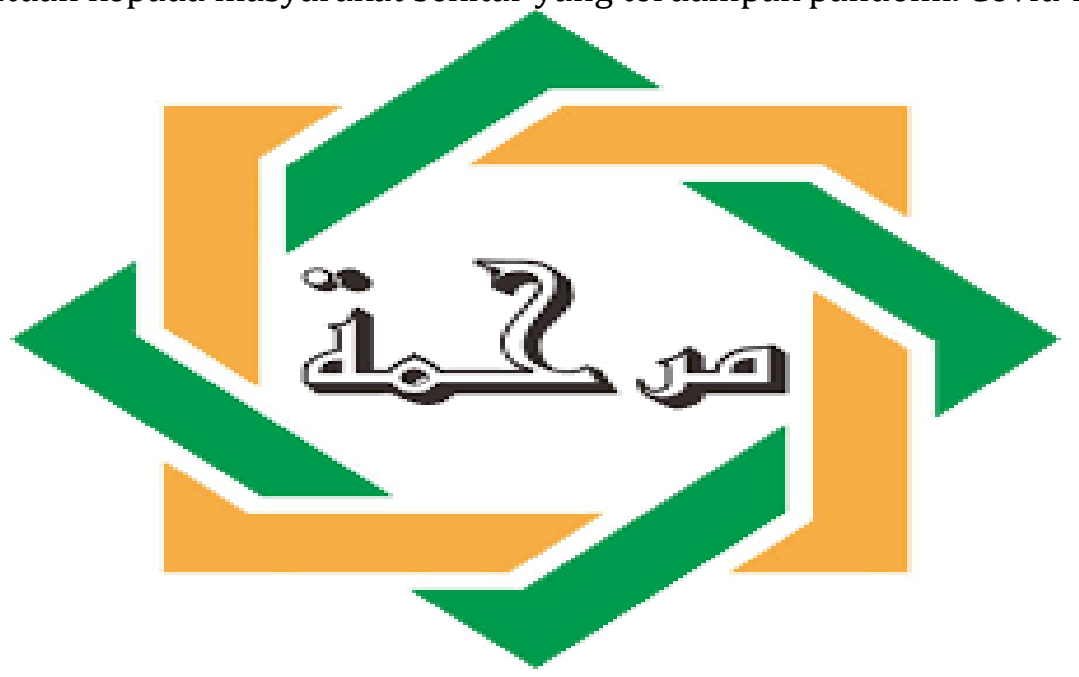

Gambar 1. Logo Marhamah Foundation

Gambar diatas adalah logo objek kegiatan PKM.
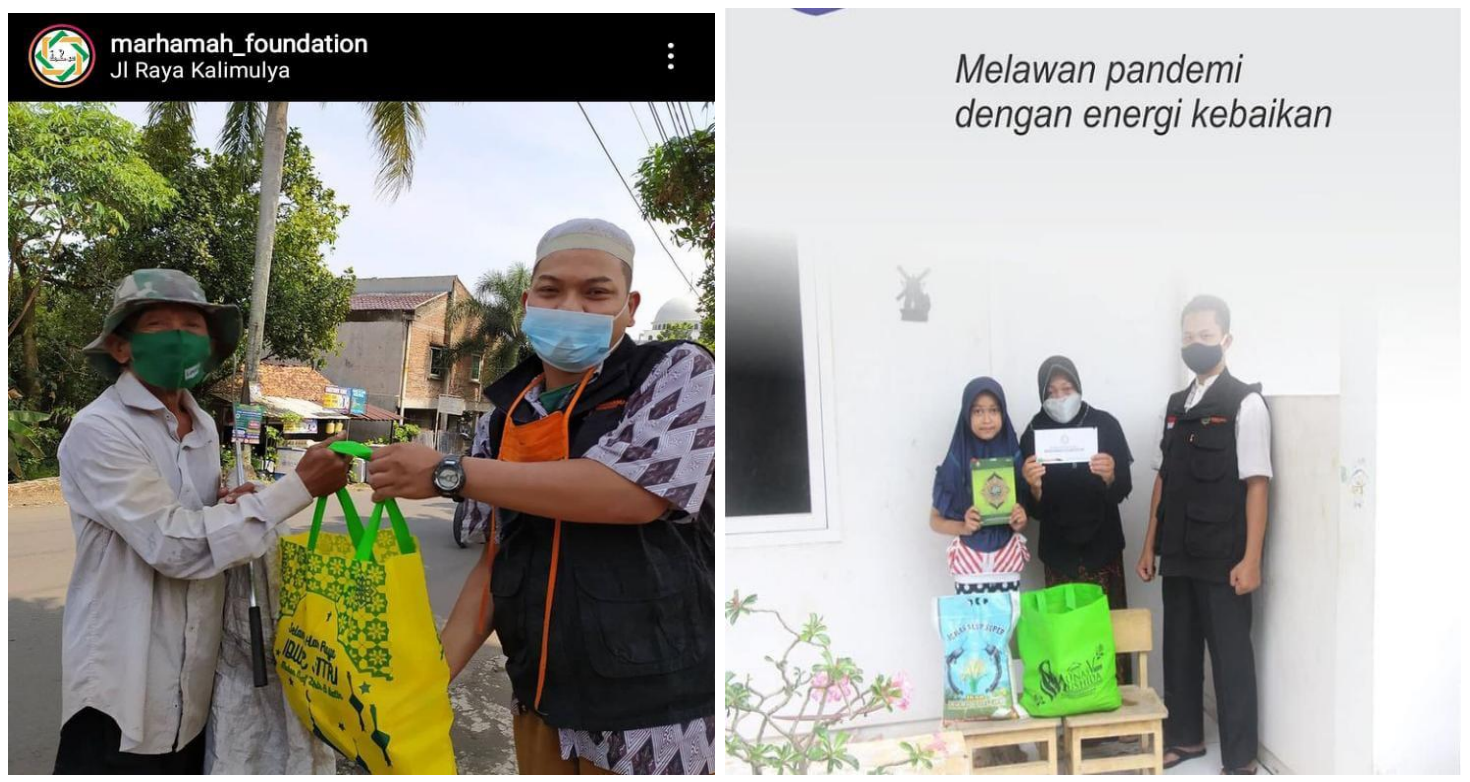

Gambar 2. Pelaksanaan Pembagian Bantuan Kepada warga sekitar

Gambar di atas merupakan kegiatan pembagian sembako yang dilakukan oleh mahasiswa STIE Hidayatullah Depok bekerjasama dengan Yayasan Marhamah Foundation kepada masyarakat sekitar yang terdapk covid 19. 

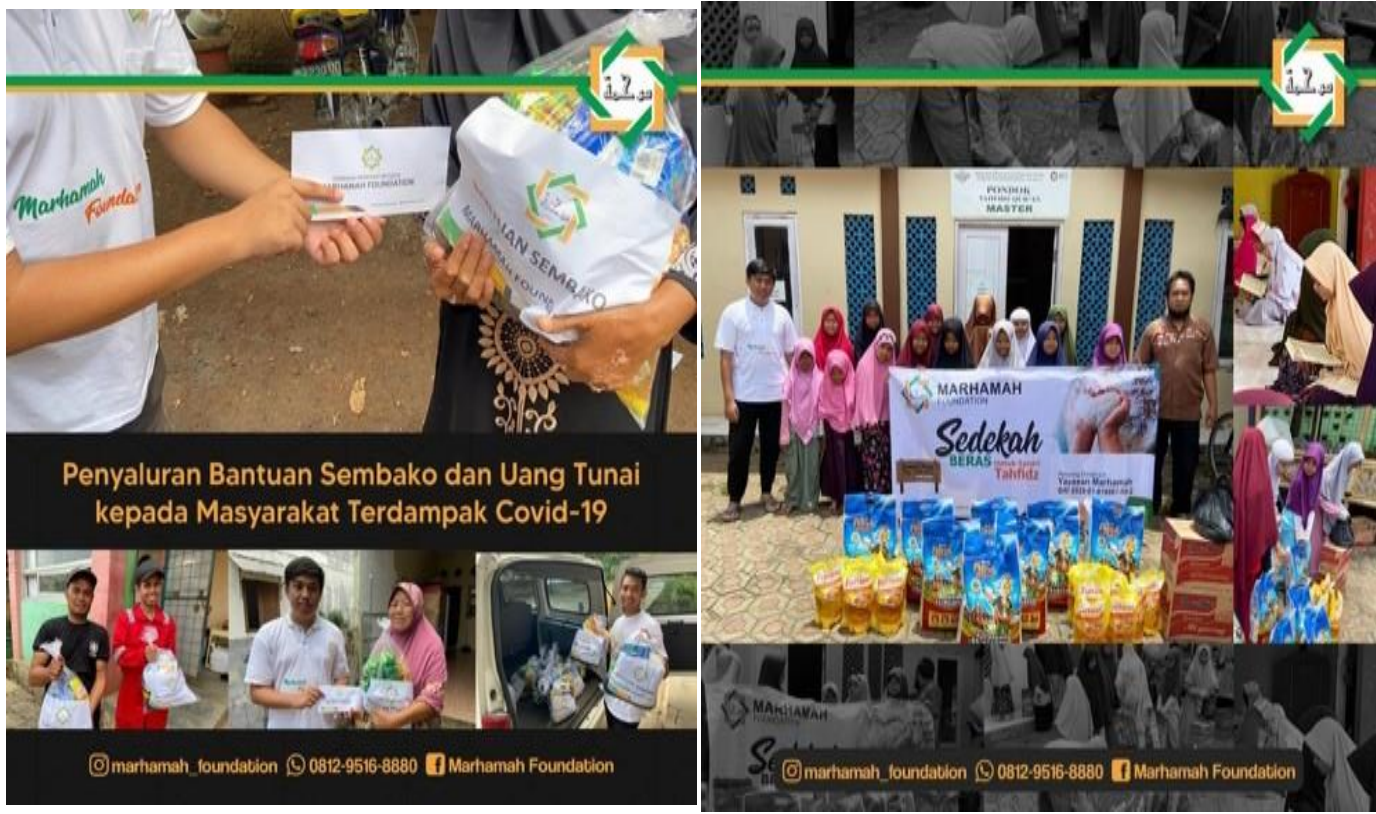

Gambar 3. Gambar pendistribusian Sembako

Gambar tersebut adalah gambar pendistribusian sembako kepada warga terdampak pandemi, baik yang sifatnya pereorangan maupun instansi Pendidikan, seperti rumah yatim yang ada disekitar wilayah cilodong Depok. ini adalah salah satu implementasi kegiatan PKM yang bertujuan untuk melakukan pembinaan dan pensejahteraan kepada seluruh lapisan masyarakat yang ada diwilayah tersebut khususnya bagi mereka yang terdampak pendemi covid 19.

\section{HASIL DAN PEMBAHASAN}

Undang-Undang RI Nomor 18 Tahun 2012 Tentang pangan, pada Bab I Pasal 4 disebutkan bahwa: Ketahanan Pangan adalah kondisi terpenuhinya pangan bagi negara sampai dengan perseorangan, yang tercermin dari tersedianya Pangan yang cukup, baik jumlah maupun mutunya, aman, beragam, berizi, merata dan terjangkau serta tidak bertentangan dengan agama, keyakinan, dan budaya masyarakat, untuk dapat hidup sehat, aktif, dan produktif secara berkelanjutan.

Sebagaiman yang dimaklumi Bersama bahawa Pandemi Covid-19 telah menyebabkan terganggunya kegiatan perekonomian di semua lini usaha baik dalam skala kecil maupun besar, termasuk sektor pertanian. Salah satu dampak yang harus diantisipasi terkait dampak Covid-19 adalah ketersediaan pangan bagi seluruh rakyat. Gerakan Ketahanan Pangan (GKP) yang diperkenalkan Kementerian Pertanian di tengah ancaman virus corona saat ini harus didukung oleh semua pihak, khususnya petani dan penyuluh sebagai ujung tombak dan penggerak sektor pertanian.

Melihat kondisi diatas, maka tidak ada alas an bagi warga Indonesia untuk tidak saling tolong menolong, saling bahu-membahu melwan covid 19 ini. Salah satu caranya adalah berbagi sembako, dimana yang kaya juga mengambil andil untuk membantu saudaranya dalam melewati masa sulit ini. Civitas academic STIE Hidayatullah bersam Marhamah Foundation hadir sebagai mediator atau perantara antara orang kaya dan orang miskin, dengan melakukan pendataan mansyarakat terdampak pandemic, kemudian membangun fanspage social media, membuat konten, menawarkan program kepada para donator,dan penyaluran bantuan kepada masyarakat terdampak pandemi. 
Perbuatan saling tolong menolong didalam agama islam adalah salah satu perbuatan terpuji yang sangat dianjurkan. " Dan tolong-menolonglah kamu dalam (mengerjakan) kebajikan dan takwa, dan jangan tolong-menolong dalam berbuat dosa dan pelanggaran. Dan bertakwalah kamu kepada Allah, sesungguhnya Allah amat berat siksa-Nya [al-Mâidah/5:2]. Syaikh as-Sa'di rahimahullah mengatakan bahwa al-birru pada ayat ini adalah sebuah nama yang mencakup segala yang Allah Azza wa Jalla cintai dan ridhai, dari perbuatan-perbuatan yang zhâhir maupun batin, yang berhubungan dengan hak Allah Azza wa Jalla atau hak sesama manusia. Dalam sebuah hadits shohih yang diriwayatkan oleh Imam Muslim bahwa Nabi Muhammad bersabda: "Barang siapa melapangkan seorang mukmin dari satu kesusahan dunia, Allah akan melapangkannya dari salah satu kesusahan di hari kiamat".

Dengan dasar ini semu civitas akademik STIE Hidayatullah Depok Bersama marhamah Foundation hadir untuk memberikan sedikit kontribusi kepada masyarakat, khususnya mereka yang terdampak covid 19, dan yang menjadi perhatian penuh pada kegiatan PKM ini adalah pengumpulan dan penyaluran sembako yang menjadi kebutukan dasar masyarakat untuk bertahan di era serba sulit ini.

Sentuhan akademisi memberi pencerahan dan sudut pandang yang luas kepada para marhamah foundation dan masyarakat baik yang berbagi maupun mereka yang menerima manfaat dari program PKM ini. Dengan adanya kegiatan PKM ini memberi dorongan kepada pengurus marhamah foundation, untuk mengetahui lebih banyak lagi cara mengelola social media untuk bisa menampung donasi yang lebih banyak, sehingga yang bisa menerima manfaat juga bisa meningkat. Melalui kegiatan PKM ini para pengurus marhamah foundation dan peserta KKN semakin tercerahkan pemahamannya bahwa apa yang sedang mereka lakukan adalah perbuatan yang mulia, menjadi mediator kebaikan.

\section{PENUTUP}

\section{KESIMPULAN}

Sebaikanya para pengurus dan mitra marhamah foundation terus berpacu untuk berbenah diri dan berusaha semaksimal mungkin dalam kegaitan fundraising dan pengelolaan social media, bahkan sampai pada level memberikan pelayanan terbaik. serta memberikan perhatian khusus kepada program yang sudah berjalan, agar kegiatan tersebut terus berkesinambungan, dan tentunya pada masa pademi ini para pengelolah diharapkan mampu menawarkan program ta'awun (Tolong-menolong) yang lebih menarik tanpa melalaikan prokes kesehatan, sehinga para donator dan penerima manfaat terus tercerhkan.

\section{SARAN}

Berdasarkan bebrapa penjelasan yang telah diuraikan oleh penulis diatas, maka ada beberapa saran yang bisa diterapkan dalam manajemen pengelolaan program kegiatan marhamah foundation diantaranya adalah:

1. Terus bertekad untuk meberikan pelayanan terbaik kepada seluruh donator dan juga penerima manfaat kegiatan ini.

2. Konten creator harus lebih aktif lagi memberikan konten-konten program yang menarik untuk ditawarkan kepara para donatur baik yang tetap maupun yang baru.

3. Kejujuran dan Transparansi dalam pengelolaan dana charity ini adalah hal yang mutlak, mengingat kegiatan ini adalah kegiatan keummatan (kemanusiaan) yang penggunaanya harus tepat sasaran agar hasilnya bisa lebih maksimal. 


\section{DAFTAR PUSTAKA}

Dewanti, R. N., et al. (2021). Penyuluhan Dan Pelatihan Keterampilan Sablon Pigment Pasta Manual Di Karang Taruna 03 Desa Cisauk. Jurnal PADMA: Pengabdian Dharma Masyarakat, $1(1)$.

Erlangga, H., et al. (2020). Pengembangan Kapasitas Usaha Kecil Kerupuk Kentang Di Kampung Ciawitali Desa Warnasari Kecamatan Pangalengan Kabupaten Bandung. Jurnal Pengabdian Tri Bhakti, 102-109.

Oktaviani, F., \& Rustandi, D. (2018). Implementasi digital marketing dalam membangun brand awareness. Profesi Humas, 3(1), 1-20.

Paeno, P., et al. (2020). Pemanfaatan Sampah Plastik Untuk Kerajinan Rumah Tangga Taman Belajar Kreatif Mekar Sari. BAKTIMAS: Jurnal Pengabdian pada Masyarakat, 2(1), 57-61.

Perdana, A., Holilulloh, M., Holilulloh,M.S., \& Nurmalisa, Y. (2013). Pengaruh Pelaksanaan Kuliah Kerja Nyata Terhadap Keterampilan Sosial Mahasiswa Program Studi $P P K N$.

Suwanto, S., et al. (2020). Menggali Potensi, Memotivasi Dan Mengarahkan Generasi Muda Menyongsong Dunia Kerja Pada PKBM Cipta Tunas Karya Cipondoh Kota Tangerang. Jurnal Pengabdian Dharma Laksana, 2(2), 132-136.

Taisîrul Karîmir Rahmân, 'Abdur Rahmân as-Sa'di, Muassasah Risâlah Cet. V, Thn. 1417H, hlm. 182

Undang-Undang RI Nomor 18 Tahun 2012 Tentang ketahanan pangan

Undang-Undang RI Nomor 20 Tahun 2003 Tentang Sistem Pendidikan Nasional Indonesia 